\title{
Discontinuation of Immunosuppressive Therapy in Patients With Neuromyelitis Optica Spectrum Disorder With Aquaporin-4
}

\section{Antibodies}

Neurol Neuroimmunol Neuroinflamm 2021;8:e1013. doi:10.1212/NXI.0000000000001013

In the article "Discontinuation of Immunosuppressive Therapy in Patients With Neuromyelitis Optica Spectrum Disorder With Aquaporin-4 Antibodies” by S.-H. Kim et al, ${ }^{1}$ Su-Hyun Kim's contributions listed in the appendix should be "Drafting/revision of the manuscript for content, major role in the acquisition of data, study concept or design, and analysis or interpretation of data." The publisher regrets the error.

\section{Reference}

1. Kim S-H, Jang H, Park NY, et al. Discontinuation of immunosuppressive therapy in patients with neuromyelitis optica spectrum disorder with aquaporin-4 antibodies. Neurol Neuroimmunol Neuroinflamm 2021;8:e947. doi: 10.1212/NXI.0000000000000947. 


\title{
Neurology \\ Neuroimmunology \& Neuroinflammation
}

\author{
Discontinuation of Immunosuppressive Therapy in Patients With Neuromyelitis Optica \\ Spectrum Disorder With Aquaporin-4 Antibodies \\ Neurol Neuroimmunol Neuroinflamm 2021;8; \\ DOI 10.1212/NXI.0000000000001013
}

This information is current as of April 19, 2021

Updated Information \&

Services

References

Permissions \& Licensing

Reprints including high resolution figures, can be found at:

http://nn.neurology.org/content/8/4/e1013.full.html

This article cites 1 articles, 1 of which you can access for free at: http://nn.neurology.org/content/8/4/e1013.full.html\#\#ref-list-1

Information about reproducing this article in parts (figures,tables) or in its entirety can be found online at:

http://nn.neurology.org/misc/about.xhtml\#permissions

Information about ordering reprints can be found online: http://nn.neurology.org/misc/addir.xhtml\#reprintsus

Neurol Neuroimmunol Neuroinflamm is an official journal of the American Academy of Neurology.

Published since April 2014, it is an open-access, online-only, continuous publication journal. Copyright $($ ) 2021 American Academy of Neurology. All rights reserved. Online ISSN: 2332-7812.

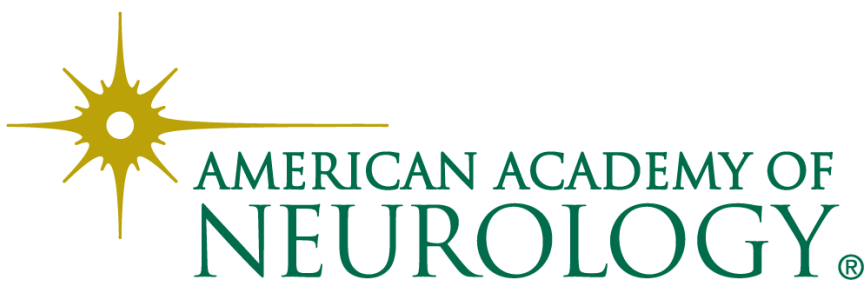

